\title{
How Important are Human Resources in Supporting Sharia Banking Performance in Indonesia?
}

\author{
Zulfikar \\ University of Malaya, Malaysia \\ zulfikarbasan61@gmail.com
}

\begin{abstract}
Research by the author is a type of research that combines qualitative and quantitative methods in looking at how influential Human Resources is on the performance of Islamic banking in Indonesia. This study takes data from the Financial Services Authority in addition to using data collection and analysis methods based on the writer's understanding by looking at the current issue. Human Resources in Islamic banking needs to be one of the main points to develop more exceptional Islamic banking and be able to survive and compete with conventional banking. HR is one of the essential factors in supporting the performance of this industry so that it can be even better in the future by applying the principles of sharia to all sharia banking workers.
\end{abstract}

Keywords: Human Resources, Islamic Banking, Performance

Permalink/DOI: https://doi.org/10.18326/infsl3.v14i2. 181-200 


\section{Introduction}

Economic activities have been since the time of the Prophet Muhammad. Economics will proceed to grow by developments in human culture. At present various sharia banks are rising with many sharia developments. Conventional economics is certainly but larger than Islamic economics. Economists prognosticate the coming year's Islamic economics will develop more immediately than conventional economics. At the time of the Prophet, there was no bank institution. However, the teachings of Islam had implemented fundamental teachings and philosophies that should use as guidelines in the business and economic activities. Hence, in trading with contemporary Muammalah matters, all that must do is to classify the basic principles and philosophies of Islamic teachings in the financial field and then recognise all things that are forbidden. Subsequent those two things do, later we can do innovation and creativity (ijtihad) to the full size to resolve all enigmas Muammalah contemporary, including banking concerns.

The progress of Islamic financial businesses in Indonesia over the past few years has been very active, although the Islamic financial market is a new element in Indonesia. That development marked by the growing number of Islamic financial institutions in Indonesia, such as Islamic banking, Islamic insurance, Islamic mutual funds, and other Islamic financial institutions. Proportionately rapid development in the Islamic financial market which has a significant influence on the people's economy is the Islamic banking industry. The Islamic banking industry can offer to transform the economy into productive, value-added and inclusive economic activities.

The critical function of the sharia banking industry in the development of the people's economy must continuously heighten by catching many possibilities that survive in the digital financial era marked by the use of technology in banking products. The competition more increased by entry into the effectiveness of the ASEAN Economic Community (MEA) in 2016 for the banking industry. That is an opportunity as well as a dare for the Islamic banking industry in Indonesia. Strangely as a new part, the market share of the Islamic banking industry in Indonesia is still low when compared to 
neighbouring countries, such as Malaysia. Apart from that if seen of the total assets of the entire banking industry, total sharia banking assets are still on the scale of 5\%. Sharia banking assets in 2016 are ranked far compared to neighbouring countries.

Accordingly, the Islamic Banking Industry necessity continues to extend itself to improve its performance in developing the economy in Indonesia. The sharia banking industry must be responsible, have a high market share, and be the option of the people. The Islamic banking industry which is a form of knowledge of the Muslim society on the utilisation of the theory of sharia in the economic field should be able to convert a significant player in the banking industry, given that greatest of the population in Indonesia is Muslim.

The development of the Islamic banking industry in Indonesia endured ups and downs, forward with the development of the conventional banking industry. Till presently, Islamic banking is besides fighting to preserve its occurrence in the financial sector, including the development manner which is quite important even though when compared to countries reported in the Islamic Finance Country Index, Indonesia is reasonably running in place. Forward with its development, the world of sharia banking also undergoes different kinds of problems, including liquidity problems, human resources, market share, and others. Those factors make the journey of the Islamic banking industry in Indonesia increasingly slow down. One crucial aspect of the management of an industry/company is Human Resources (HR). If management has problems correlated to its human resources, it will at least affect the company's development performance. In the banking world, in particular, the purpose of HR is significant competent and professional human resources demanded both theoretical and practical issues.

The dilemma of Human Resources is a classic problem that can most found in all sectors of government, including the Islamic banking sector because of a lot of competent and adequate human resources connected to conventional banks, while these joining Islamic banks were very few. Hence that the ordinary human resource in Islamic banks cannot change banking products, and understanding sharia arrangements is also a problem in itself plus 
the incompetence in shariah in opinion and implementing principles. Because this human resource is one of the principal purposes of why Islamic banking has not prepared to develop optimally in Indonesia, the majority of the population is Muslim. It is agreeable, with the loss of compliance of human resources in Islamic banks, which disclaims something that should own.

The total assets of Islamic banks in November broke through IDR 400 trillion for the first time. Islamic Banking Statistics The Financial Services Authority (OJK) notes that sharia banks' assets in November 2017 grew 12.6\% to Rp 401.45 trillion from the end of the previous year. The amount consists of Rp 278 trillion Sharia Commercial Bank and Sharia Business Unit (UUS) valued at Rp 123.4 trillion. At present, there are 34 sharia banks, consisting of 34 Sharia Commercial Banks and 21 UUS banks, with a total of around 57 thousand employees. The Third Party Funds (DPK) collected up to November 2017 reached Rp 322.7 trillion with profit-sharing financing of Rp 112.75 trillion. In November 2017, the Islamic banks' Capital Adequacy Ratio (CAR) reached 17\%, and the financing ratio to third parties (FDR) was $80.07 \%$. At the same time, the rate of problematic financing (NPF) reached 5.27\%.

To support the growth and improvement of Islamic banking as described above, Indonesia must have the potential framework to reveal it. The Islamic finance industry currently wants human resources (SDI) that are genuinely professional and qualified who can know not only at the conceptual level except also at the practical level of Islamic economics. While its development, this industry still gets an actual performance, that is among the development of the Islamic banking industry and the regularity of the quality of its human resources. The growth of the Islamic finance industry should have scales compared to the problems of its human resources. That is, the Islamic banking industry yet embarrassed by some obstructions compared to human resources including, the gap in HR qualification standards between university graduates and production in the field, to the insufficient understanding of practitioners of Islamic banking.

On the other hand, the partnership between education worlds 
and the banking industry still lacks, because connections and matches have not yet fully transpired. Moreover, investment in education and development recruitment for bankers who are ready to use is moderately expensive. The problem of Human Resources in Islamic banking is a problem that needs to interpret concurrently. One of the problems of HR in Islamic banking is the lack of cooperation between academics and practitioners in printing HR. In fact, with that can print quality HR for the needs of the sharia banking industry in Indonesia another problem in terms of education is the lack of availability of literature, lecturers, and researchers related to sharia economics in Indonesia. That is what causes the creation of useful human resources is still constrained. Source Human power is a very determining element of the development and progress of Islamic banks.

Mainly in banking which is engaged in services, where the elements of people interacting high with customers, the quality of service delivered cannot separate from the role of the employees who become human resources in it. How employees' behaviours, intentions, and attitudes lead to high-quality service can be strategically directed through existing practices and policies in HR management. Therefore it can be accepted that internal practices in an organization, including practices and policies in human resource management have the potential to impact on organizational performance concerned. Competition in the banking industry, especially Islamic banking, is not only among Islamic commercial banks. The many players are conventional local and foreign traditional banks that open Sharia Business Units (UUS).

Of course, the conditions of competition challenges all bank to advance the excellence of its services to the public. As a service corporation, customers/customers required in the service offering manner, and there is close intercommunication between employees and customers. That's why is the HR factor in the service sector so vital because it cannot entirely replace by technology. Furthermore, the connection with customers in Islamic banks is more about partnerships that are oriented not only to profit but also to Falah adaptp ed alias happiness in the afterlife. In contrast to conventional banks in the form of a debtor-creditor relationship. Because of the high 
reputational risk nature, it places importance on current HR systems for advancing representation in Islamic banks.

Sharia banking practitioners now are still dominated by conventional transfer groups. So, reasonably the soul that is in the heart of Islamic banking practitioners, the majority are besides in the stage of how they can execute-not yet approached the level of how they can improve so that the socialization program frequently revealed ostensibly because of a disproportion among data that socialized with the facts that develop. Principal, systematic and planned synergies from all practitioners structurally demanded to modify the quality of employees who were beforehand conventional to the sharia banking practice. Of course, this must follow by support from the government (Ministry of Finance, BI, related departments), ulama, parliament (DPR / DPRD), universities, businessmen (Muslim reporters), Islamic organizations and Islamic societies in the general ground the Islamic economy.

The equivalence between socialization and community education from all associated groups, as mentioned above. Furthermore, it is also essential to continue betterment to the economic system regulations in Indonesia that are destructive and following the objectives of the maslahah for all Indonesian people. Because of discursively the theory of the capitalist and colonial economy which is still not insulated from the device of the nation's economy, including influences the mindset of the people as subjects and objects of the economic system in general and banking in particular.

Islamic banking in Indonesia needs to have substantial human resources (HR) competent in understanding sharia principles. Throughout this time, there are still many sharia banking human resources coming from conventional banks. Hence that the condition affects the adoption of a profit-sharing system (Murabaha) instead abandoned, all sharia banks in Indonesia until now there are not many who practice sharia principles. It needs to be a trigger for Islamic banking to have reliable HR who know sharia principles. It is time to improve the management of HR banking in sharia to clear the accurate sharia banking system. 


\section{Literature Review}

HR management is a significant component of the organization's management businesses. Whence well HR managed will manage the organization's success in the future. Conversely, if HR not correctly managed, effectiveness will not stretch. Human Resources (HR) is one of the most vital elements of the organization. That appeared because first, HR dramatically determines the efficiency and effectiveness of organizations, HR patterns and makes goods and services, manages quality, markets products, allocates financial resources, and identifies all organizational purposes and policies. Second, HR is an enormous investment of the organization in managing the business. Because of the greatness of this HR management, if neglected, the organization will not receive in accomplishing its goals and objectives (French, 1986).

One significant concern that wants consideration is the quality of human resources. The role of HR is very strategic as the administrator of company functions, namely planning, organizing, leadership, and supervision as well as fulfilling company operations, such as marketing, production, trade, industry, finance, and administration. All directors must be involved in the HR process in an integrated manner. To accomplish proposed objectives in the organization process managers allocate organizational resources with ideas that have been made based on a corporate construction, establish authority and responsibilities, recruit and select, conduct training and development, and place HR in the right position. It is these organizing activities that deliver extraction to HR management.

According to John R. Schermerhorn, HR management is the manner of withdrawing, improving, and managing workers. None separate from Thomas S. Bateman and Scott A. Snell, management $\mathrm{HR}$ is a manner as well as an attempt to recruit, develop, motivate, and appraise the overall HR demanded by the company in accomplishing its aims. Therefore, the activities brought out in HR management start of choosing anyone equipped and proper to maintain a space in the company (the right man in the right place) to encourage and strengthen workers. HR management is a continuous process, which is in involvement with the method of company services so that attention to HR remains a special place in the company's 
organization. Consequently, in the management of HR workers are the principal assets from the company that must satisfactorily control so that the factor of matter in HR management is the people themselves.

Further, respectively, Human Resources activities that are particular to the management capacity are 1) Planning, which circumscribes goals and criteria, establishes systems and methods, establishes plans or prognostications for the future. 2) Organizing, namely presenting specific jobs to each HR, developing job analysis or job analysis, establishing communication, coordinating work within superiors and subordinates. 3) Leadership, which is attempting for others to accomplish the task that is their responsibility, increase morale, motivate employees. 4) Supervision, which sets standards for achieving work results, quality standards, conducting reviews of work results, and delivering corrective actions as needed. The achievement or failure of the implementation of superintendence purposes is very dependent on the quality of its human resources. It shows how important and imperative development is to change the quality of human resources in organizations that proceed to grow in line with the demands of the globalization era. Variety human resources will determine the future of the company's business back and forth.

This human resource problem is no longer a new thing in the world of the Islamic banking industry. So far, it known that the quality of human resources in Islamic banking is developing quite well, followed by the development of the sector. However, several research studies prove that the most prominent problem in the world of Islamic banking is the problem of human resources. Aam Slamet Rusydiana explained that one of the factors is a limitation to the development of the sharia banking industry in Indonesia is inadequate skilled and professional human resources. The first factor, according to Amirus Sodiq, is the weak understanding of sharia banking practitioners in business development and sharia matters. In other words, not yet satisfied equipped human resources in the field of Islamic economics, so that inhabit, Islamic banking frequently differs from the principle sharia. Second, supply located. Practitioners can only describe what they know but cannot answer 
what people ask. Third, unfinished skilled and expert human resources, mostly managerial technical.

Meantime, according to Muhammad Tho'in, the completion of his research showed that understanding of sharia products, as well as an understanding of sharia postulates, was great because it encouraged by factors of education, training and experience that played a significant role. Whereas at the worker level, it repudiates the manager level because of determinants in education, training and experience that are not yet qualified. That means that the development of the quality of Islamic banking human resources has not been able to follow developments in terms of capacity.

HR affects the success of each company or organization. HR management aims to progress, supplying to productive people who are in the business through several ways that are strategically, ethically, and socially responsible-extension backer for HR to better organizational effectiveness to accomplish goals (Werther and Davis, 1996). HR management concentrates on training activities and connections between employees to be able to show optimal appearance. The workers can increase their ability and technical knowledge to actualize the goals installed in the planning.

The role of HR management is indispensable for the achievement of a productive, effective and efficient workforce. The original brand of HR management is how to find or get the best person and how to sustain it. How do you get the best people for the jobs accessible in company organizations? How to preserve and keep it? Automatically, the complete rule termed the HR management process. In this process, the first engagement that must carry out is the abandonment of a qualified workforce, which involves HR planning, contracting, and selection. Second, the development of workforce quality provisions for orientation, training, and worker development. Third, the preservation of workforce quality includes support and turnover of workers, performance assessment, and compensation.

The process of HR management is all methods correlated to the struggles carried out beginning from HR planning, recruitment, signing of work contracts, placement of workers, to coaching, and 
workforce development. That process helpful for setting and sustaining workers in specific positions, skills and competencies by the terms given to workers the work.

All management activity ordinarily starts with planning. Accordingly, HR planning in company operations is also a necessity. HR planning affords a framework for combining decision-makers, ultimately the organization. HR planning is one representation of strategic planning, as well as financial planning, marketing, and production. Leslie W. Rue and Liod L. Byars in Management Skills and Applications formulating human resource planning is the process of arranging several social eligibilities properly for the best position at the right time. Tisnawati Sule and Kurniawan Saefullah defined, human resource planning is strategic planning to manage human resource qualifications which needed for company organizations in accomplishing company goals. Its role is directly related to organizational strategy. HR planning involves supply and demand analysis, including forecasting. That indicates HR planning is a process of review and identification of the need for human resources and their availability so that the organization can accomplish its objectives (Mathias and Jackson, 2004).

Inside each business, even though the manager knows every activity carried out every day, HR planning is still demanded. The need for HR planning in organizations is imperative. That means that the focus of HR management planning is appropriate steps taken by management to ensure that in the company there is the right HR available to maintain various positions and jobs at the right time as well. All of them, to achieve the goals and objectives that have achieved set.

There are several strategic steps for human resource planning, mainly, First, the representation and appearance of the company's strategic plan correlated to HR planning. That means that the HR qualifications that expressed should meet the criteria as required in the company's overall strategic planning, integrated with other parts of the company, such as the production, marketing, and so forward. For illustration, companies in the next five years plan to secure a profit rate of $10 \%$. Hence, the personnel department must 
assure that the HR recovered and acquired can support the system for the company.

Second, the interpretation of job requirements to be carried out by workers. This step is an effort to explain the work qualifications needed to achieve the company's strategic purpose. At this stage, three things usually are done, namely (1) Job analysis or better known as job analysis specific demands about the type of work required and the qualifications of the workforce competent of carrying it out. The final results of job review are job specification and job stipulation. (2) Job description includes job features that will be the tasks, responsibilities and foreseeable consequences of operations in a particular occupation. (3) Job blueprints are aspects of the qualifications, abilities, skills and characteristics required for business success in precise jobs.

HR planning is a well-organized process related to predicting HR demand and availability in the prospect. HR planning has an essential position in developing an organizational strategic plan. The implementation of HR management purposes must carry out consistently. As an example, the use and character of HR management in achieving an organization's mission is the process of recruitment, selection, and training to get skilled and proficient workers by the needs to achieve goals organization. Another complementary functions, such as the performance appraisal system and compensation management, are functions maintaining the success of an organization's strategic planning. HR planning wants to start with an HR inventory activity that already started in the company. With HR planning, the company can completely utilize the current HR in the company.

Through careful HR planning, business effectiveness can also further improved if the existing HR as per company needs. Productivity can further be enhanced if it has data on the knowledge and training work that has been attended by HR. HR planning is concerned with determining needs workforce in the future, both in terms of numbers and qualifications to fill various positions and conduct multiple new activities. The HR plan is the base for the development of work programs for work units that control inter- 
nal HR company. Without HR planning, it won't be straightforward to develop practical business programs. The presence of complete data about the potential of HR will make it more accessible to select a more sophisticated and more accountable program.

Through HR planning, the company can optimize current HR as well as possible so that the efficiency, effectiveness and productivity of the company can be improved. Therefore, proper planning is supposed necessary for the effectiveness of management in the company. Through HR planning, future workforce needs can be designed, both in numbers and their qualifications to fill several positions, as well as purchasing workers according to need. HR planning can help companies set focused strategic aims by appropriating talented and skilled personnel.

\section{Methods}

The method used was a combination of qualitative and quantitative approaches with investigation and secondary data from the Financial Services Authority. Data interpretation in this research is the process of systematically searching and collecting data gathered from interviews, field notes and different materials so that they can be surely understood and their decisions can share with others. The implementation of the analysis is interactive, in which the process carried out both when the data collection is still ongoing, for illustration in the form of correlations within data units, data grouping, and when data gathering is over, in the development of statements which includes the final stage of analysis.

The population of this research is all Sharia Banks in Indonesia that offer sharia products, both in the form of Sharia Commercial Banks, Sharia Rural Banks and Sharia Business Units at conventional commercial banks. The cumulative number of banks in Indonesia is 14 Sharia Commercial Banks. As for the analysis, the sample is all Islamic banks that have operated in Indonesia. These models with the consideration that this study examines HR management practices, which practice is a long continuous process and interrelated between one function with the function of others in HRM. 


\section{Results and Discussion}

Islamic banking is a bank institution that operated with Islamic systems. The occupancy or establishment of Islamic banking should depart from physical requirements with the people's decision or economic demands. Then, for an Islamic bank to sustain and expand, its institutional management must be reliable, and the implementation of its business activities must be professional. The expansion of Islamic banks in Indonesia, of course, there must be assistance from quality human resource management because a sharia bank can't realise success without able sharia HR management.

Islamic banks, namely face one problem that is no less complex: First, the issue of human resources. In this case, the rise of Islamic banking in Indonesia not equaled by sufficient human resources. Exceptionally HR, who has experience knowledge in the field of Islamic banking. Second, the scarcity of Islamic banking academics, where much knowledge is more oriented to the installation of conventional economics rather than Islamic economics, which during the turn involved with Islamic economics mostly Islamic banking ignored and got less concentration. The development of Islamic banking, of course, must be supported by adequate human resources, both in terms of quality and quantity. However, the reality shows that there are still many human resources which have involved in Islamic institutions do not have academic and practical experience in Islamic Banking. Necessarily this condition significantly transforms the productivity and professionalism of Islamic banking itself.

\section{Table 1. Development of Total Assets, Office Networks and Sharia Banking Workforce (Islamic Banking in Indonesia)}

\begin{tabular}{cccccc}
\hline Year & $\begin{array}{c}\text { Total Assets } \\
\text { (in billion } \\
\text { IDR) }\end{array}$ & $\begin{array}{c}\text { Number } \\
\text { of Banks }\end{array}$ & $\begin{array}{c}\text { Number } \\
\text { of Offices }\end{array}$ & ATM & $\begin{array}{c}\text { Number of Hu- } \\
\text { man Resoucrse }\end{array}$ \\
\hline 2016 & 254.184 & 13 & 1.869 & 3.127 & 51.110 \\
2017 & 288.027 & 13 & 1.825 & 2.585 & 51.068 \\
2018 & 316.691 & 14 & 1.875 & 2.791 & 49.516 \\
\hline
\end{tabular}




\begin{tabular}{cccccc}
\hline Year & $\begin{array}{c}\text { Total Assets } \\
\text { (in billion } \\
\text { IDR) }\end{array}$ & $\begin{array}{c}\text { Number } \\
\text { of Banks }\end{array}$ & $\begin{array}{c}\text { Number } \\
\text { of Offices }\end{array}$ & ATM & $\begin{array}{c}\text { Number of Hu- } \\
\text { man Resoucrse }\end{array}$ \\
\hline 2019 & 350.364 & 14 & 1.919 & 2.827 & 49.654 \\
2020 & 349.950 & 14 & 1.923 & 2.827 & 49.923 \\
\hline
\end{tabular}

Table 2. Correlations

\begin{tabular}{|c|c|c|c|c|c|c|}
\hline & & $\begin{array}{c}\text { Total } \\
\text { Assets }\end{array}$ & $\begin{array}{l}\text { Number } \\
\text { of Bank }\end{array}$ & $\begin{array}{l}\text { Number } \\
\text { of Offices }\end{array}$ & ATM & $\begin{array}{c}\text { Human } \\
\text { Resour- } \\
\text { ces }\end{array}$ \\
\hline \multirow{4}{*}{$\begin{array}{l}\text { Total } \\
\text { Assets }\end{array}$} & Pearson & 1 & $.899^{*}$ & .757 & -.366 & -.841 \\
\hline & Correlation & & & & & \\
\hline & $\begin{array}{c}\text { Sig. } \\
\text { (2-tailed) }\end{array}$ & & .038 & .138 & .545 & .074 \\
\hline & $\mathrm{N}$ & 5 & 5 & 5 & 5 & 5 \\
\hline \multirow[t]{2}{*}{$\begin{array}{l}\text { Number } \\
\text { of Bank }\end{array}$} & $\begin{array}{c}\text { Pearson } \\
\text { Correlation }\end{array}$ & $.899^{*}$ & 1 & .796 & -.116 & $-.982^{* * *}$ \\
\hline & $\begin{array}{c}\text { Sig. } \\
\text { (2-tailed) }\end{array}$ & .038 & & .107 & .853 & .003 \\
\hline \multirow{2}{*}{$\begin{array}{c}\text { Number } \\
\text { of } \\
\text { Offices }\end{array}$} & $\begin{array}{c}\text { Pearson } \\
\text { Correlation }\end{array}$ & .757 & .796 & 1 & .325 & -.703 \\
\hline & $\begin{array}{c}\text { Sig. } \\
\text { (2-tailed) }\end{array}$ & .138 & .107 & & .594 & .185 \\
\hline \multirow[t]{2}{*}{ ATM } & $\begin{array}{c}\text { Pearson } \\
\text { Correlation }\end{array}$ & -.366 & -.116 & .325 & 1 & .144 \\
\hline & $\begin{array}{c}\text { Sig. } \\
\text { (2-tailed) }\end{array}$ & .545 & .853 & .594 & & .818 \\
\hline \multirow{2}{*}{$\begin{array}{l}\text { Human } \\
\text { Resour- } \\
\text { ces }\end{array}$} & $\begin{array}{c}\text { Pearson } \\
\text { Correlation }\end{array}$ & -.841 & $-.982^{m * *}$ & -.703 & .144 & 1 \\
\hline & $\begin{array}{c}\text { Sig. } \\
\text { (2-tailed) }\end{array}$ & .074 & .003 & .185 & .818 & \\
\hline
\end{tabular}

From the results of the SPSS correlation table above, it can conclude that: Total Assets -0.841 means perfect correlation with 
negative relationship forms. The number of Bank -0.703 means strong correlation with harmful types of relationship. The number of Bank -0.9882 means ideal correlation to the kind of a negative relationship. While ATM 0.144 , there is no correlation and positive relationship.

Table 3. Model Summary

\begin{tabular}{|c|c|c|c|c|c|c|c|c|c|}
\hline \multirow[b]{2}{*}{$\begin{array}{l}\text { Mo } \\
\text { del }\end{array}$} & \multirow[b]{2}{*}{$\mathrm{R}$} & \multirow[b]{2}{*}{$\begin{array}{l}\text { R Squ } \\
\text { are }\end{array}$} & \multirow{2}{*}{$\begin{array}{l}\text { Adju } \\
\text { sted R } \\
\text { Square }\end{array}$} & \multirow{2}{*}{$\begin{array}{l}\text { Std. Error } \\
\text { of the } \\
\text { Estimate }\end{array}$} & \multicolumn{5}{|c|}{ Change Statistics } \\
\hline & & & & & $\begin{array}{l}\text { R Square } \\
\text { Change }\end{array}$ & F Change & df1 & df 2 & $\begin{array}{l}\text { Sig. F } \\
\text { Change }\end{array}$ \\
\hline 1 & $1.000^{\mathrm{a}}$ & 1.000 & & . & 1.000 & . & 4 & 0 & . \\
\hline
\end{tabular}

From the summary table above, it can also explain that $0<0.05$ is correlated. If you see the value of $\mathrm{R}=1,000$, it means perfectly correlated.

One factor that prepares to increase the representation of bank institutions is the availability of adequate human resources and supporting infrastructure. Sufficient human resources required by Islamic banks are those who are accurately aware of the thought of Islamic banks and Islamic economics, and psychologically they have a high Islamic spirit. HR who only understand the knowledge of Islamic banking and Islamic economics, but do not have a tremendous Islamic vision, the experience is like there is no spirit. So that in his daily activities, he has no insight of belonging and a sense of responsibility towards the progress of Islamic banks.

Conversely, HR who have a high Islamic spirit but do not have knowledge about Islamic banks or Islamic economics, he is like a person who walks without direction. Until now, it is yet rare for Islamic banking practitioners to have both of these things. Therefore Islamic banks must try to consider increasing human resources so that they can support experience in Islamic banking, and are also psychologically prepared to build the spirit of Islam.

Attempts to prepare Islamic banking human resource qualifications in the future need to be ready as well as possible to compete with conventional banking. They mainly focused on efforts to increase professionalism that is not only related to the issue of 
expertise and skills but far more critical related to moral commitment and business ethics for the profession to be run. Understanding and the unreal manifestation of religious, moral values is an absolute requirement for future sharia banking players.

By understanding the vertices of the problems that occur and the policies that have made, to realize the quality of Islamic banking human resources, it needs to focused on efforts that lead to increased understanding of related aspects, such as shareholders and managers/administrators of sharia banking. The challenges and opportunities that exist require a struggle with high religious values, it needs to be continued by Islamic financial and educational institutions to grow sincere Islamic banking human resources.

To overcome these obstacles, a severe effort needed in the context of developing Islamic banks in the future: First, improving the quality of human resources in the field of Islamic banking. One of them is to develop an education system that integrates the theory and practice of Islamic banking to improve the integrity of Islamic banks amid society. Second, the need for further progressive struggles from each party disquieted about the survival and development of Islamic banks both from the government, scholars, banking practitioners, especially academics. Including, third, provide the most obvious opportunity for conventional banks to open sharia branch offices, which are proficient of legality and materiality, to establish Sharia Commercial Banks in all corners of the country.

The HR required by Islamic banking is an HR character who has capabilities in the economic field and combined with Islamic skills. Besides this, it can say that ideally, Islamic financial institutions in the prospect will need actual human resources. Attempting to build a sincere Islamic banking human resources, in the future, is a troublesome task. This task needs to be carried out by all parties related to Islamic finance, especially Islamic Banking. Therefore, the world of education must take an active and proactive role in shaping and providing qualified human resources.

In practice, until now, most of the HR in Islamic financial institutions do not come from Islamic economics graduates, but other majors. Their sharia knowledge generally obtained through technical 
training conducted internally by banks or short courses organized by Islamic banking training institutions. That is what should get our attention, which is to produce human resources who are capable of practising Islamic economics on all fronts because a sound system cannot run if useful human resources do not support it.

The role of HR in organizations or companies has the same meaning as the work itself, given the importance of HR in the organization. HR as a determining factor for an organization, competence is an aspect that determines the success of organizations with high competencies possessed by human resources. That will determine the quality of human resources owned, which in turn will determine the competitive quality of the company itself. Sharia banking human resources demanded to have morals and competencies based on reliable qualities (trustworthy), have high integrity (shiddiq), and always bring and spread goodness (tabligh), and have expertise and knowledge that is reliable (fathanab). Therefore, ideally, HRs who work in Islamic banks are people who have excellent knowledge and competence in the financial sector, as well as understanding sharia principles.

\section{Conclusion}

Islamic banking demands to further optimized in delivering its immediate plans for future industrial development, both product development strategies, human resources management and other operational. Acknowledging Indonesia is the most prominent Muslim majority country in the world; it has the vital potential to develop finances sharia in this era of globalization.

Nevertheless, it does not only focus on the development of its financial performance but also puts its development focus on the management and quality of its human resources, so that the process of sharia banking expedition within industry development and the variety of human resources Islamic banking is suitable. Additionally, HR is the most crucial factor to advance Islamic banking in the future because HR is one of the movers in running the Islamic banking system. HR must have the qualifications that are needed by Islamic banking, which not only see the ability to work alone, but also look at the knowledge of muammalah in Islamic economics. 


\section{References}

Alamsyah, H. (2010). Perkembangan dan Prospek Perbankan Syariah Indonesia. Jakarta.

Armansyah. (2002). Intelegency Quotient, Emotional Quotient, and Spiritual Quotient dalam Membentuk Perilaku Kerja. Jurnal Ilmiah Manajemen \& Bisnis. Vol. 02 No. 01.

Bariroh, Muflihatul. (2019). Implementasi Manajemen Hati Sebagai Upaya Peningkatan Sumber Daya Manusia di Mayangkara Group. An-Nisbah: Jurnal Ekonomi Syariah. Volume 05, Nomor 02.

French, Wendell L. (1986). Human Resource Management. Boston : Houghton Mifflin Company

Ginting Munthe, Jasman (2012). Proyeksi Kebutuban Sumber Daya Manusia (SDM) Perbankan Syariah dan Skenario Pemenuhannya. Tesis, Jakarta : Universitas Indonesia,

Haryanto, Rudy (2010). Bagi Hasil dan Bank Syariah (Solusi terhadap Bunga Bank). Al-Ahkam. 5(2)

https://www.ojk.go.id/id/kanal/syariah/data-dan-statistik/statistikperbankan-syariah (2020)/Pages/Statistik-Perbankan-Syariah--Januari-.aspx

Husserl, E. (2006). Basic Problems of Phenomenology. Netherlands: Springer.

Ivancevich, J.M. (2007). Human Resource Managament. New York: McGraw Hill.

Kenedi, Jon (2013). Analisis Praktek Manajemen SDM Perbankan Syariah Milik Pemerintah Di Sumatera Barat. Jurnal Ekonomi STIE Haji Agus Salim Bukittinggi, XIV (2),

Khan, Tahreem Noor (2015). Closing the Gaps of Human Resource in Islamic Banks: Literature Review Analysis. International Journal of Business and Social Science, 6 (5),

Kuswarno, E. (2009). Fenomenologi: Konsepsi, Pedoman, dan Contoh Penelitiannya. Bandung: Widya. 
Mathias, Robert L. dan John H Jackson (2004). Human Resource Management. Singapore: Cengage Learning Asia Pte Ltd,

Moleong, Lexy J (2004). Metodologi Penelitian Kualitatif. Jakarta: Rosda Karya,.

Muhammad. (2005). Metodologi Penelitian Kualitatif Manajemen Bank Syari'ah. Yogyakarta: UPP AMP YKPN.

Muhammad. (2000). Lembaga Keuangan Kontemporer. Yogyakarta: UII Press,

Mujib, Abdul dan Yusuf Mudzakir (2002). Nuansa-nuansa Psikologi Islami. Jakarta: PT. Raja Grafindo Persada,

Nawawi, Hadari. (2011). Manajemen Sumber Daya Manusia: untuk Bisnis yang Kompetitif. Yogyakarta: Gadjah Mada University Press,

Noe, R.A. et.al. (2003). Human Resources Management. Boston: Mc Graw-Hill

Pheng, L.M. \& I.J. Detta. (2007). Islamic Banking \& Finance Law. Malaysia: Pearson Longman.

Rama, A. (2015). Analisis Deskriptif Perkembangan Perbankan Syariah di Asia Tenggara. Journal of Taubidinomics, 1(1), 1-25.

Rivai, Veithzal. (2004). Manajemen Sumber Daya Manusia untuk Perusahaan dari Teori ke Praktik. Jakarta: PT Raja Grafindo,

Rusydiana, A. S. (2016). Analisis Masalah Pengembangan Perbankan Syariah di Indonesia: Aplikasi Metode Analytic Network Process. Esensi: Jurnal Bisnis dan Manajemen, 6(2), 237-246.

Sari, M. D., Bahari, Z., \& Hamat, Z. (2013). Perkembangan Perbankan Syariah di Indonesia: Suatu Tinjauan. Jurnal Aplikasi Bisnis, 3(2), 120-138.

Simamora, H. (2004). Manajemen Sumber Daya Manusia. Yogyakarta: STIE YKPN.

Siswanto. (2011). Meningkatkan Daya Saing Sumber Daya Insani Perbankan Syariah melalui Implementasi Praktek Quran-Based HRM. Proceeding Forum Riset Perbankan Syariah $V$. 
Sodiq, Amirus. (2018). Analisis SWOT Perkembangan Perbankan Syariah Di Indonesia. MALIA: Journal of Islamic Banking and Finance 1.1

Sugiyono. (2007). Metode Penelitian Kuantitatif Kualitatif dan $R$ \& $D$. Bandung: Alfabeta

Syukron, A. (2013). Dinamika Perkembangan Perbankan Syariah di Indonesia. Economic: Journal of Economic and Islamic Law, $3(2), 28-53$.

Tho'in, M. (2016). Kompetensi Sumber Daya Manusia Bank Syariah Berdasarkan Prinsip-Prinsip Syariah Islam (Studi Kasus Pada BNI Syariah Surakarta). Jurnal Ilmiah Ekonomi Islam, 2(03).

Utama, A. S. (2018). Sejarah dan Perkembangan Regulasi Mengenai Perbankan Syariah Dalam Sistem Hukum Nasional Di Indonesia. Jurnal Wawasan Yuridika, 2(2), 187-200.

Werther, William B, dan Keith Davis. (1996). Human Resource Management. Mc.GrawHill,.

Zubair, M. K. (2008). Akselerasi Pertumbuhan Bank Syariah di Indonesia. Millah: Jurnal Studi Agama, 8(1), 1-16. 